
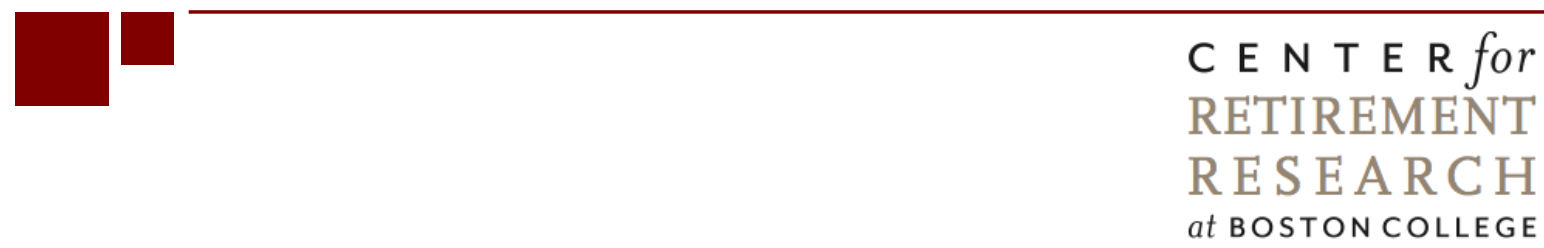

\title{
CAN KNOWLEDGE EMPOWER WOMEN TO SAVE MORE FOR RETIREMENT?
}

\author{
Drew M. Anderson and J. Michael Collins \\ CRR WP 2017-12 \\ September 2017
Center for Retirement Research at Boston College
Hovey House
140 Commonwealth Avenue
Chestnut Hill, MA 02467
Tel: 617-552-1762 Fax: 617-552-0191
http://crr.bc.edu

Drew M. Anderson is a post-doctoral researcher at the University of Wisconsin-Madison. J. Michael Collins is the faculty director of the Center for Financial Security at the University of Wisconsin-Madison. The research reported herein was performed pursuant to a grant from the U.S. Social Security Administration (SSA) funded as part of the Retirement Research Consortium. The opinions and conclusions expressed are solely those of the authors and do not represent the opinions or policy of SSA, any agency of the federal government, the University of Wisconsin-Madison, or Boston College. Neither the United States Government nor any agency thereof, nor any of their employees, makes any warranty, express or implied, or assumes any legal liability or responsibility for the accuracy, completeness, or usefulness of the contents of this report. Reference herein to any specific commercial product, process or service by trade name, trademark, manufacturer, or otherwise does not necessarily constitute or imply endorsement, recommendation or favoring by the United States Government or any agency thereof. The authors would like to thank Shelly Schueller, Tarna Hunter, and Michael Hogard of the Wisconsin Employee Trust Funds, and Emily Lockwood of Empower Retirement for their cooperation and support.

(C) 2017, Drew M. Anderson and J. Michael Collins. All rights reserved. Short sections of text, not to exceed two paragraphs, may be quoted without explicit permission provided that full credit, including (C) notice, is given to the source. 


\title{
About the Steven H. Sandell Grant Program
}

This paper received funding from the Steven H. Sandell Grant Program for Junior Scholars in Retirement Research. Established in 1999, the Sandell program's purpose is to promote research on retirement issues by scholars in a wide variety of disciplines, including actuarial science, demography, economics, finance, gerontology, political science, psychology, public administration, public policy, sociology, social work, and statistics. The program is funded through a grant from the Social Security Administration (SSA). For more information on the Sandell program, please visit our website at: http://crr.bc.edu/?p=9570, send e-mail to crr@bc.edu, or call (617) 552-1762.

\section{About the Center for Retirement Research}

The Center for Retirement Research at Boston College, part of a consortium that includes parallel centers at the University of Michigan and the National Bureau of Economic Research, was established in 1998 through a grant from the Social Security Administration. The Center's mission is to produce first-class research and forge a strong link between the academic community and decision-makers in the public and private sectors around an issue of critical importance to the nation's future. To achieve this mission, the Center sponsors a wide variety of research projects, transmits new findings to a broad audience, trains new scholars, and broadens access to valuable data sources.

\author{
Center for Retirement Research at Boston College \\ Hovey House \\ 140 Commonwealth Ave \\ Chestnut Hill, MA 02467 \\ Tel: 617-552-1762 Fax: 617-552-0191 \\ http://crr.bc.edu
}

Affiliated Institutions:

The Brookings Institution

Syracuse University

Urban Institute 


\begin{abstract}
Retirement-account balances are lower among women than men. This study assesses the role of financial knowledge and empowerment in contributing to the gender gap in savings. We evaluate the effects of financial education delivered to women in the workplace, using administrative data on 31,000 public-sector workers in Wisconsin. All of these workers participated in a mandatory defined-benefit pension plan, but 47 percent also participated in a deferred compensation savings instrument provided by their employer, with the median participant contributing 1.6 percent of earnings each month. In a triple-difference strategy, we compare the progression of gender gaps in savings over time at state agencies that implemented financial education with the group that did not. We estimate that a multi-media education effort increased participation in retirement savings by 2.6 percentage points, closing the gender gap by more than half. This result is partially explained by pre-existing trends. The education program operated at low marginal cost and is likely to be portable to other contexts.
\end{abstract}

The paper found that:

- Differences between men and women in financial knowledge and motivation contribute to gender gaps in retirement savings.

- Financial knowledge and motivation can be augmented by multimedia financial education.

The policy implications of the findings are:

- One tool for employers to increase savings is financial education.

- The main channel appears to be motivation of new participation in savings through repeated communication of key facts via multiple media and peer interaction. 


\section{Introduction}

Even though women live longer and, therefore, face higher costs during retirement, they save less for retirement than men do. Women start at a disadvantage for wealth accumulation because of lower earnings and labor supply over their lifetimes (GAO 2007). This study focuses on a large public workforce where women also save a lower percentage of their incomes and take on lower-return investments. A potential explanation for these gaps is that women have lower levels of financial literacy and engagement in household financial decisions (Lusardi and Mitchell 2008).

Financial literacy and engagement could be improved at relatively low cost, relative to changing lifetime earnings, labor supply, or health. Financial literacy cannot be shared among household members or passed on to survivors, making it all the more important for women who will spend long periods of retirement single (Munnell, Sanzenbacher, and King 2017). In general, financial education often has no discernible effect on behavior, but a recent study showed that workplace financial education increased budgeting and saving, particularly among women (Collins and Urban 2016). This study examines the effects of an intervention targeted specifically to increase women's retirement savings through information and motivation.

In 2015, several state agencies in Wisconsin implemented a multimedia education effort called Embracing and Promoting Options for Women to Enhance Retirement (EMPOWER). We estimate the effects of EMPOWER using monthly longitudinal data for a workforce of 31,000 employees for four years surrounding the program's implementation.

To isolate the effect of the program, we employ a triple-difference strategy comparing men to women, before and after implementation, at agencies that implemented the program versus other agencies that did not. This strategy has a strong claim to estimating causal effects of EMPOWER on retirement savings, controlling for differences across agencies in levels of savings and gender gaps in savings, and controlling for time trends in savings.

To our knowledge, this is the first study to use large-scale administrative data on the retirement accounts of public-sector employees. Evidence on public-sector retirement savings has, to date, been based on surveys which lack detail on either the type of plan or on individual characteristics (Copeland 2014). Our data allow us to make a unique contribution to the financial education literature, where outcomes are often short-term measures of planned behavior, rather than long-term measures of actual financial behavior. 
We find that workplace financial education and peer-to-peer motivation increase retirement savings in this context. Wisconsin state workers are required to contribute to a pension fund, but 47 percent also participate in a deferred-compensation savings instrument similar to a 401(k), with the median participant contributing 1.6 percent of their earnings each month. EMPOWER increased participation in the deferred-compensation instrument by 2.6 percentage points, closing the gender gap in participation by more than half. The EMPOWER program operated with very low marginal costs, and is likely to be portable to other contexts.

We subject this result to several robustness checks and find that pre-existing trends explain some of the closing of the gender gap at EMPOWER agencies. While we detect an increase in participation in savings, there is not clear evidence that workers already participating contributed more of their incomes to retirement savings. Much of the increase in participation is driven by younger workers.

The remainder of the paper expands on the background, setting, empirical strategy, results, and overall conclusions.

\section{Gender Gaps in Retirement Savings}

Women face a different set of problems at the end of life than men do (Papke, Walker, and Dworsky 2008). Women tend to live longer than men, which means that they may need to have more set aside for their retirement years, and they may be facing those years alone. Accumulating savings is more difficult for women since they earn less than men do at the same jobs, choose lower paying jobs, are more likely to work part-time, and take more time off of work to care for children and elders (Goldin 2014; Munnell 2004; Wettstein and Zulkarnain 2017). In many contexts women also take less financial risk, and therefore earn lower returns on investments (Sundén and Surette 1998; Bajtelsmit, Bernasek, and Jianakoplos 1999; Bajtelsmit and Jianakoplos 2000; Dwyer, Gilkeson, and List 2002; Charness and Gneezy 2012). ${ }^{1}$ To overcome all of these disadvantages, women must contribute a larger percentage of their earnings toward retirement savings. Hindering this process are higher expenditures on healthcare and student loan payments (Dieleman et al. 2016; AAUW 2017).

Recent evidence shows that women's savings are catching up. Using data from the March Current Population Survey (CPS), Copeland (2014) measured the percent of wage and

\footnotetext{
${ }^{1}$ Other studies find no difference by gender, including Papke (1998) and Papke (2003).
} 
salary workers aged 21 to 64 who participated in an employer-based retirement plan. The gap between men and women closed from 10.3 percentage points in 1987 to 0.5 percentage points in 2013. More recent administrative data on millions of private-sector workers eligible for definedcontribution workplace plans show that women are 7 percentage points more likely to save, and save 0.4 percentage points more of their earnings (Young 2015; Fidelity Investments 2017). One factor helping to close the gender gap and raise rates of participation overall is auto-enrollment in savings (Young 2015).

The remaining gaps in participation between men and women were largest among publicsector workers (Copeland 2014). In the public sector, workplace plans are much more commonly offered (82 percent versus 51 percent in the private sector) and are much more likely to be mandatory defined-benefit plans (Munnell et al. 2011; Copeland 2014). This implies that the remaining gap in participation between men and women arises from differential participation in elective plans, such as in states where optional defined-contribution programs are the primary plan, or where workers participate in supplemental deferred-compensation plans. The survey data available in both the CPS and the Survey of Consumer Finances (SCF) do not clearly separate these two public-sector options for saving in deferred-compensation plans, and the SCF does not identify public-sector workers. The National Compensation Survey cannot distinguish gender gaps in savings.

These deficits in measurement are important in Wisconsin, where nearly half of the public workforce participates in an elective deferred-compensation plan, above and beyond required contributions to a defined-benefit pension. The state does not auto-enroll workers into the defined-contribution plan, leaving supplemental saving decisions up to workers.

Deciding to save is clearly positively correlated with financial knowledge (Fernandes, Lynch, and Netemeyer 2014; Lusardi and Mitchell 2014). Therefore gender gaps in saving may be exacerbated by gaps in knowledge and motivation. Evidence from a special 2004 supplement to the Health and Retirement Study (HRS) shows that women nearing retirement have low levels of financial literacy and are unlikely to have planned for retirement at all (Lusardi and Mitchell 2008). Similar results are found in the National Financial Capability Study (Bucher-Koenen 2016). ${ }^{2}$

\footnotetext{
${ }^{2}$ In a more detailed but smaller-scale survey, self-assessments of financial preparedness were similar between men and women (Prudential Financial 2015).
} 
The consequences of lower saving, and the role of information in increasing savings, are less clear (Hastings, Madrian, and Skimmyhorn 2013; Munnell, Rutledge, and Webb 2014). Using a life-cycle optimization model of financial behavior, most Americans' levels of saving appear high enough to support consumption during retirement (Scholz, Seshadri, and Khitatrakun 2006; Gale, Scholz, and Seshadri 2009). If households are indeed optimizing, it is unlikely that choice architecture or financial education will shift their choices. Auto-enrollment does increase savings in multiple contexts (Beshears et al. 2009). At the same time, financial education generally has little to no effect on behavior (Fernandes, Lynch, and Netemeyer 2014).

Evidence on the power of workplace financial education in particular is somewhat more promising (Lusardi and Mitchell 2007). Studying workplace financial education that was delivered to both men and women, Clark et al. (2006) found that women were more likely to plan to increase contributions, while Collins and Urban (2016) found women actually do increase contributions at higher rates as a result of education that they received. Other notable studies of workplace financial education find no difference in impacts for men and women, or do not examine gender differences but find impacts could be largest for those who save the least (Bernheim and Garrett 2003; Duflo and Saez 2003). Lusardi and Mitchell (2008) call for educational programs that are long-term, and specifically address women's preferences and saving needs, but to our knowledge no such program has been directly evaluated until now.

\section{Efforts to Close Gender Gaps in Wisconsin}

\section{Wisconsin State Workers}

The Wisconsin state workforce is employed at a variety of central and statewide agencies. This study focuses on 20 of the largest non-school employers. The Department of Employee Trust Funds provided administrative data for all retirement system eligible employees in each month from April 2013 through April 2017. The data include personal characteristics, yearly labor supply and earnings, and monthly participation in retirement accounts.

Table 1 displays characteristics of these state agencies in March 2015 before the implementation of the EMPOWER financial education program. The agencies are grouped based on whether they participated in EMPOWER, and then sorted by employee size. 
Table 1. Characteristics of Workers at Wisconsin State Agencies

\begin{tabular}{|c|c|c|c|c|c|}
\hline Agency & Employees & $\begin{array}{c}\text { Median } \\
\text { wage }(\$)\end{array}$ & $\begin{array}{c}\text { Women } \\
\text { (\%) }\end{array}$ & $\begin{array}{l}\text { Median } \\
\text { age }\end{array}$ & $\begin{array}{c}\text { Median } \\
\text { tenure } \\
\text { (yrs.) }\end{array}$ \\
\hline Overall & 30,580 & 23.39 & 50.1 & 45 & 12 \\
\hline \multicolumn{6}{|l|}{ EMPOWER-participating } \\
\hline Health Services & 5,830 & 21.38 & 65.1 & 45 & 9 \\
\hline Transportation & 3,340 & 26.95 & 38.2 & 46 & 14 \\
\hline Administration & 920 & 32.22 & 39.6 & 51 & 14 \\
\hline Agriculture, Trade, Cons. Protection & 600 & 24.54 & 47.2 & 47 & 11 \\
\hline Military Affairs & 440 & 18.65 & 29.2 & 49 & 8 \\
\hline Employee Trust Funds & 250 & 28.49 & 58.5 & 49 & 10 \\
\hline Insurance & 140 & 30.36 & 52.1 & 52 & 14 \\
\hline Housing and Econ. Development & 140 & 32.78 & 60.8 & 50 & 13 \\
\hline Financial Institutions & 120 & 29.60 & 51.6 & 48 & 11 \\
\hline \multicolumn{6}{|l|}{ Non-participating } \\
\hline Corrections & 9,550 & 21.93 & 42.0 & 44 & 13 \\
\hline Natural Resources & 2,750 & 26.06 & 35.0 & 46 & 14 \\
\hline Workforce Development & 1,610 & 21.38 & 64.6 & 47 & 10 \\
\hline Veterans' Affairs & 1,320 & 17.29 & 79.8 & 46 & 6 \\
\hline Revenue & 1,050 & 26.38 & 52.5 & 49 & 13 \\
\hline Children and Families & 730 & 25.23 & 78.6 & 44 & 8 \\
\hline Public Instruction & 650 & 28.38 & 66.5 & 47 & 13 \\
\hline Justice & 620 & 29.38 & 57.2 & 42 & 12 \\
\hline Safety and Professional Services & 200 & 26.28 & 51.5 & 51 & 13 \\
\hline Investment Board & 160 & 71.54 & 41.1 & 44 & 8 \\
\hline Public Service Commission & 150 & 32.98 & 49.0 & 50 & 16 \\
\hline
\end{tabular}

Note: Includes all Wisconsin Retirement System eligible employees as of March 2015.

Source: Wisconsin Employee Trust Funds.

The agencies are diverse in terms of size, wages, and demographics, but there are no systematic differences between the EMPOWER group and comparison agencies. Employee size varies from a low of 120 at one agency to seven organizations with more than 1,000 employees each. Median wages across all 20 agencies are \$23.39 per hour. While the workforce is balanced between men and women overall, the gender breakdown varies widely by agency, with women comprising more than two thirds of employees at health- and education-related agencies, including the Departments of Health and Human Services, Veterans' Affairs, Children and 
Families, and Public Instruction. Two of the largest employers, the Departments of Corrections and Natural Resources, employ mostly men. Overall there is a correlation of -0.24 between median wage and percentage women on staff across employers, but the relationship is not monotonic. The median age is 45 with a median tenure on the job of 12 years, with slight variations by agency.

The state of Wisconsin offers two main retirement savings programs for its employees, in addition to Social Security: the Wisconsin Retirement System (WRS) and Wisconsin Deferred Compensation (WDC).

WRS is a mandatory pension program with defined-benefit and defined-contribution elements (http://etf.wi.gov/publications/et8901.pdf). In 2017 workers contribute 6.6 percent of their pre-tax income with a full employer match. Retirees are entitled to a benefit which is the higher of two formula-based calculations, one based on the three highest years of earnings and the other based on the balance of employee and employer contributions. The WRS therefore acts most like a defined-benefit pension plan for the majority of workers, for whom the contribution payout is lower. By default, all contributions are invested in a "fully diversified, balanced" Core Fund with mostly equities, but workers can elect to invest half of their contributions in a Variable Fund with greater risk. Additional non-matched contributions are optional. Our data include an indicator for participation in the Variable Fund, and a yearly overall balance, but we cannot identify when workers provide additional non-matched contributions.

WDC provides the opportunity for supplemental savings under Section 457 of the Internal Revenue Code (http://etf.wi.gov/publications/et8904.pdf). Workers can make either pretax or post-tax (Roth) contributions of up to \$18,000 per year, with additional “catch-up” amounts for workers over the age of 50. Participants can invest contributions across 6 target date funds and 16 options in the core investment spectrum, as well as thousands of mutual fund choices through a self-directed brokerage option. Retirement benefits can be received as a lumpsum or an annuity. Our data include monthly deferrals and balances to pre- and post-tax WDC plans.

WDC is similar to 401(k) plans available to private-sector workers, but is more flexible. First, 457 balances can be withdrawn before retirement with no penalty (though taxes must be paid at withdrawal of pre-tax accounts). Second, 457 contributions are not coordinated with 
401(k) contributions, meaning 401(k) contributions by the worker or spouse do not count toward the yearly limit.

\section{Gender Gaps at Wisconsin State Agencies}

Wisconsin data are consistent with several of the overall trends noted in prior research: women earn less than men do, they are less likely to take on investment risk, they are less likely to participate in retirement savings, and they save lower percentages of their income when they do participate. The gender gaps persist after controlling for observable characteristics.

At nearly every agency, the median man earns more than the median woman does. Figure 1 shows box plots of yearly earnings by agency. The agencies are grouped as in Table 1, by participation in EMPOWER and then sorted by employee size. Earnings are calculated based on employee's average hourly earnings over the study period, and scaled to a full-time full year of work for each employee. The box spans the interquartile range with a line at the median. The whiskers extend to the adjacent values, which are the minimum and maximum observations that are still within 1.5 interquartile range lengths outside the interquartile range. The plots display workers employed in March 2015, and are also divided by gender within each agency. In most cases each quantile for men is higher than each quantile for women at the same agency. The graph excludes the State of Wisconsin Investment Board, which has much higher earnings than other agencies and also has a large gender gap. 
Figure 1. Men Earn More than Women Do

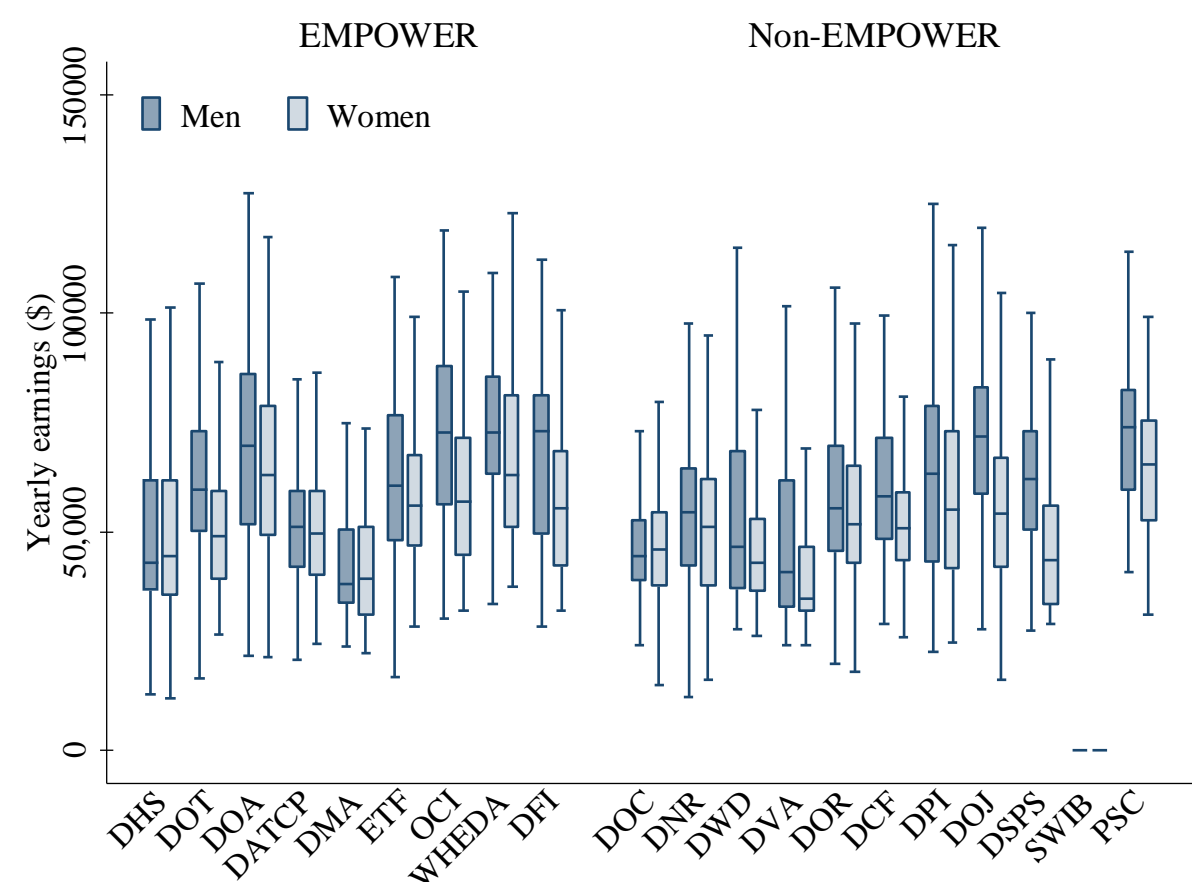

Note: Includes all Wisconsin Retirement System eligible employees as of March 2015. Source: Wisconsin Employee Trust Funds.

The gender wage gap is not completely explained by observables. In raw averages, women earn $\$ 4,640$ less for a full year of full-time employment, or 91.6 cents on the dollar as compared to the average earnings among men. After controlling for individual age, tenure, employer, marital status, race, and part-time status in a regression, the estimated effect of gender is $\$ 4,210$, implying that women earn 92.4 cents on the dollar. Additional relevant characteristics such as education level and job title are not observed in these data.

Men take more investment risk. Figure 2 shows the rate of participation in the WRS Variable Fund for investing pension balances. The gender gap is present at nearly all agencies. Overall, women are 2.3 percentage points less likely to participate, at 19.0 percent compared to a 21.3 percent rate of participation among men. After regression controls (as described above) this difference falls from 2.3 to 1.4 percentage points. 
Figure 2. Men Take More Investment Risk than Women Do

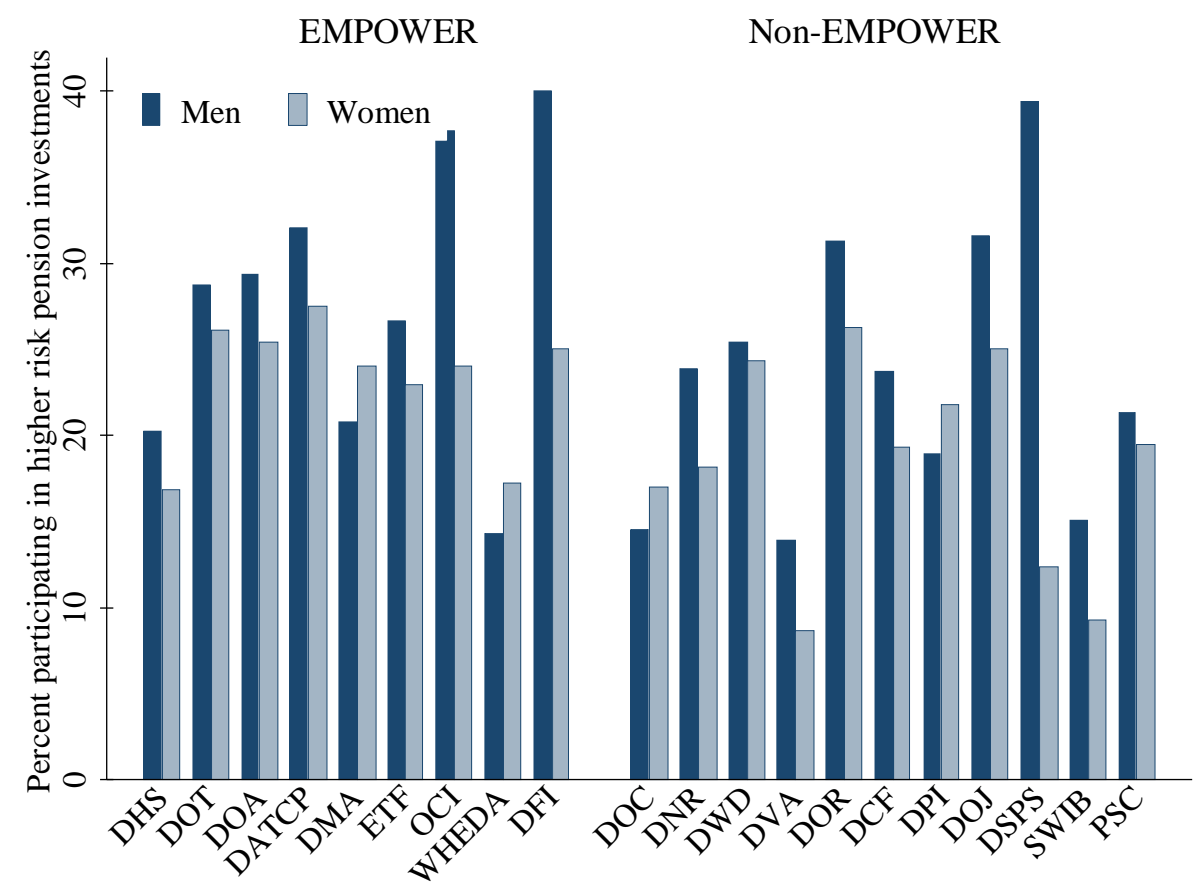

Note: Includes all Wisconsin Retirement System eligible employees as of March 2015.

Source: Wisconsin Employee Trust Funds.

Men are more likely to participate in WDC, and to contribute higher amounts when they do participate. Gender gaps in WDC savings are shown in more detail, including trends over time, in the triple difference analysis below. These gaps provided the motivation for the EMPOWER financial education and motivation program.

\section{Embracing and Promoting Options for Women to Enhance Retirement (EMPOWER)}

The Department of Employee Trust Funds administers the state pension fund as well as defined-contribution plans for state employees. The Department became aware of gender gaps in retirement contributions and set about researching causes and potential solutions, in collaboration with researchers from the University of Wisconsin-Madison (Holden and Kock 2012). The result of this effort was the development of the EMPOWER program.

EMPOWER delivered information, motivation, and challenges through multiple media over the span of a few months. Each employee received a monthly email with facts such as "women are twice as likely as men to live in poverty during retirement," and links to online 
resources about financial planning and retirement savings through the employer. Employees also received invitations to webinars, and live events for women only. The central events were hosted during lunch at work. There was no incentive for participation, no time off from work granted, and no meal provided. Shelly Schueller of the Department of Employee Trust Funds reported that most employers had never done anything like this before, and many were that worried nobody would show up. In many cases the room was filled to capacity, with more people standing outside the door. The meetings generated contact to the Department for one-onone financial counseling sessions and for changes in retirement savings. We use administrative data and comparison groups to confirm whether the impact on participation was significant, and to measure the size of the impact on savings amounts.

Figure 3 and Figure 4 provide some examples of EMPOWER educational materials. The theory of change of EMPOWER is that peer interaction is an effective medium for information and motivation, especially women talking to other women co-workers. This theory emerged from surveys and focus groups conducted by Holden and Kock (2012). Studies in behavioral finance show that people are averse to talking about finances, especially perceived deficits or negative outcomes (Karlsson, Loewenstein, and Seppi 2009). EMPOWER could combat this "ostrich effect" by enforcing the norm that talking about finances is accepted and encouraged. EMPOWER materials pointed out deficits in women's preparation for retirement, but always offered ways to move toward planning and saving. 


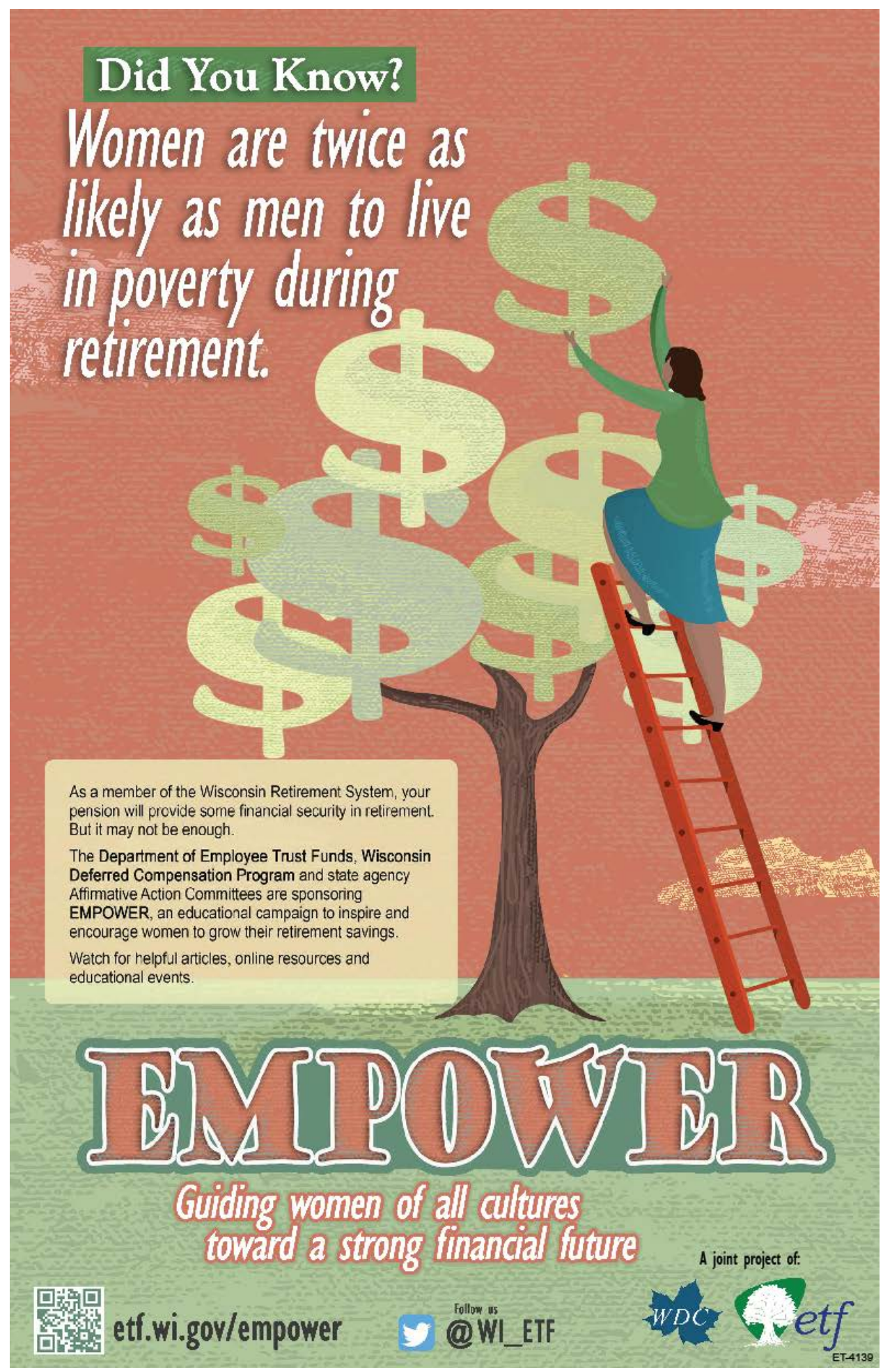

Source: Wisconsin Employee Trust Funds. 


\section{Get To Know Your Sources of Retirement Income}

- Social Security ssa.gov/myaccount

- Wisconsin Retirement System (WRS), your employer-sponsored retirement plan etf.wi.gov

- Wisconsin Deferred Compensation (WDC) wdc457.org

- What do you AND your spouse/partner have? 401(k), 403(b), IRA, etc.

\section{$4 \mathrm{C}_{\mathrm{eff}}$}

Source: Wisconsin Employee Trust Funds.

In response to EMPOWER, households could take several actions to shift their household finances. A relatively obvious and low-risk action is to increase savings in WDC. Since the plan has tax advantages and no penalties for withdrawal, saving in WDC combines long-term, automated savings endorsed by the workplace with the flexibility of short-term liquid savings that remain available for emergencies.

The EMPOWER program was presented to representatives of each agency serving as Affirmative Action Officers. These Officers are tasked with ensuring equity and inclusion, as set forth in Wisconsin Statute Chapter 320, Administrative Rule ER 43. Each individual representative had the discretion to determine whether employees at their agency could benefit from EMPOWER.

At employers where EMPOWER was chosen for implementation, monthly checklists were created, committing each employer to undertake communications and events during each 
month over an eight-month span. For all participating employers, implementation began in April 2015. Each agency had a representative assigned to send emails, post literature around the office, field questions from employees about EMPOWER, and coordinate events.

Fidelity of implementation varied across agencies. Wisconsin Employee Trust Funds collected data on EMPOWER activities at each participating agency, but activity reporting also varied in consistency. In summary, about half of the agencies were considered to have fully implemented EMPOWER, while others partially implemented it and/or supplemented assigned activities with their own related measures.

The next section discusses our strategy for measuring behavioral responses among EMPOWER's target population.

\section{Estimating the Effects of EMPOWER}

The selection and rollout of EMPOWER financial education at the agency level allow for estimation of the causal effect of the program, without the selection bias that would be present if individuals sought out the program themselves. As discussed above, the program was selected by individual community representatives at 9 of the 20 large employers, who then coordinated to begin the program together in April 2015 and to continue it over the following eight months. The program was directed specifically at women. The key outcomes affected by financial education are participation in WDC, and amount contributed among participants.

\section{Specification}

Our triple-difference strategy measures whether the gender gap in savings closed after EMPOWER was introduced, relative to the gap at places where EMPOWER was not introduced. We compare the EMPOWER target population to other workers not exposed to EMPOWER: women employed at other agencies, the same employees before the implementation of the program, and men employed at the same agencies. We first present retirement outcomes graphically by month, for each of these four groups. We then show the changes in retirement savings for each of the four groups, and calculate each relevant difference-in-difference (for example the relative change at EMPOWER agencies versus others among women only). Finally we estimate the triple-difference effect. 
The triple-difference can be estimated as a linear combination of eight cell means interacting men/women, before/after, and EMPOWER/non-EMPOWER. The following equation produces the exact same estimate as the coefficient on a triple-interaction term, and allows for the addition of various other terms as controls. We include successive rounds of covariates, trends, and fixed effects to condition out potential confounders.

Equation (1) models retirement savings choices $Y_{i t}$ for individual $i$ in month $t$ employed at agency $E(i t)$, as a function of indicators for gender (female $F_{i}$ ), whether the agency ever participated in EMPOWER (treatment $T_{E(i t)}$ ), and whether the month is April 2015 or later (post-implementation $P_{t}$ ).

$$
Y_{i t}=\rho T_{E(i t)} F_{i} P_{t}+\eta_{1} T_{E(i t)} F_{i}+\eta_{2} T_{E(i t)} P_{t}+\eta_{3} F_{i} P_{t}+\gamma T_{E(i t)}+\zeta F_{i}+\delta P_{t}+\varepsilon_{i t}
$$

\section{Estimation}

Estimating this equation with our data has several implications. First, we do not observe whether an individual participated in any EMPOWER activities, only where workers are employed each month. This means that some employees counted as "treated" will not have engaged with EMPOWER activities. Some may not have even been employed during the months when EMPOWER was active. The estimated effects can therefore be thought of as employer-level intent-to-treat effects on the rates of participation and savings upon implementing an education program like EMPOWER. In some specifications we limit our focus to employees who did not change employers, and estimate within-person effects.

Second, even setting aside the small number of workers who change employers, the data constitute an unbalanced panel because workers enter and leave the workforce. The employment at the 20 agencies in the study in any given month is roughly 31,000, which is stable over the 49month period of our sample. In each month, about 1 percent of workers enter the workforce and 1 percent leave. We observe a total of 43,363 individuals. The agency $E$ (it) is denoted with a time index because workers can change agencies, though just 2.2 percent of workers ever do.

Third, the outcome $Y_{i t}$ is defined in two ways. To estimate extensive margin effects it is defined as a binary indicator for participation, where a value of $Y_{i t}=1$ means the worker is currently making either pre- or post-tax deferrals to WDC. Workers commonly move in and out of WDC participation while employed. Of the workers who ever participate in WDC, 13.5 
percent will stop deferrals at least once while they are still employed. To estimate intensive margin effects $Y_{i t}$ is defined as the total number of dollars contributed in pre- and/or post-tax deferrals, as a percentage of monthly earnings (the intensive margin). Monthly earnings are calculated for each individual as a weighted average monthly wage, because hours and earnings data are only available at a yearly frequency. When a worker is not contributing, $Y_{i t}=0$. To separate the intensive margin effects from joining effects, we limit this analysis to workers who had contributed to WDC during the period before EMPOWER was implemented (47 percent of the sample).

Fourth and finally, in regression estimates we cluster standard errors by agency, which is the level of the policy change (Moulton 1986; Bertrand, Duflo, and Mullanaithan 2004). There are 20 agencies, but over 1.4 million person-month observations. Clustering therefore tends to increase standard errors greatly.

\section{Identification}

$\rho$ identifies the effect of EMPOWER if there is no correlation between the error term $\varepsilon_{i t}$ and the triple-interaction term $T_{E(i t)} F_{i} P_{t}$. This assumption will hold if there are no omitted factors affecting participation or contributions to retirement savings, that are also coincident with the timing, gender targeting, and agency targeting of EMPOWER. We know of no other policies implemented with the same timing and targeting as EMPOWER. Baseline differences in the savings rates of women, as well as baseline differences in gender gaps, are conditioned out of our comparisons. We show below that agencies taking up EMPOWER did have larger gender gaps in retirement savings on average. Bias must come from differential in trends in gaps, that would occur absent the introduction of EMPOWER.

Bias could arise if selection into EMPOWER by Affirmative Action Officers was correlated with trends in gender gaps in savings. For example, if representatives who foresaw more growth in gender gaps decided to use EMPOWER as a countermeasure, our results would be biased toward finding a smaller impact. Conversely if representatives who took up EMPOWER were also engaged in more independent activities to close gender gaps in savings, our results would be biased toward finding a larger impact. We cannot rule out these possibilities, but the panel data allow us to look for differential trends in gaps during the preimplementation period, and to control for trends directly. 
The coefficient $\rho$ is an average across all types of workers. Our data also allow for testing of heterogeneous effects by individual characteristics of workers or agencies. In particular, we explore whether EMPOWER has a greater effect on younger workers (below age 50), and on married versus unmarried workers. To do so we break up the sample and estimate regressions separately for each group.

Some other improvements on Equation (1) include controlling for additional person-level variables such as marital status, age, and race/ethnicity. We go a step further and use the panel structure of the data to include person fixed effects, controlling for anything about individuals that is time-invariant.

We can also allow for more flexible estimation by using quarter indicators for the tripledifference term, rather than one indicator for the post-EMPOWER period. This event-study specification makes the most of our multi-period data as emphasized in Wolfers (2006). This approach shows whether there appear to be triple-difference shifts before EMPOWER, a way of evaluating the assumption of parallel progression of gender gaps. It also shows whether effects decay or persist after implementation.

\section{Effects of EMPOWER}

This section reports results starting from a comparison of means and proceeding through various regression adjustments. In each setting we report effects on participation and contribution outcomes.

\section{Graphical Results}

Figure 5 shows our empirical strategy graphically. The figure tracks the progression of gender gaps in retirement savings at agencies that implemented EMPOWER, versus agencies that never implemented EMPOWER. In both groups of agencies, men are more likely to participate than women. EMPOWER agencies have a larger initial gender gap, and lower rates of participation overall. Controlling for all of these level differences, we look for divergence in the gender gap after implementation of EMPOWER. The small rise in the "EMPOWER, women” line after implementation, relative to the other three lines, suggests a positive effect of the program. 
Figure 5. Extensive Margin Effects of EMPOWER

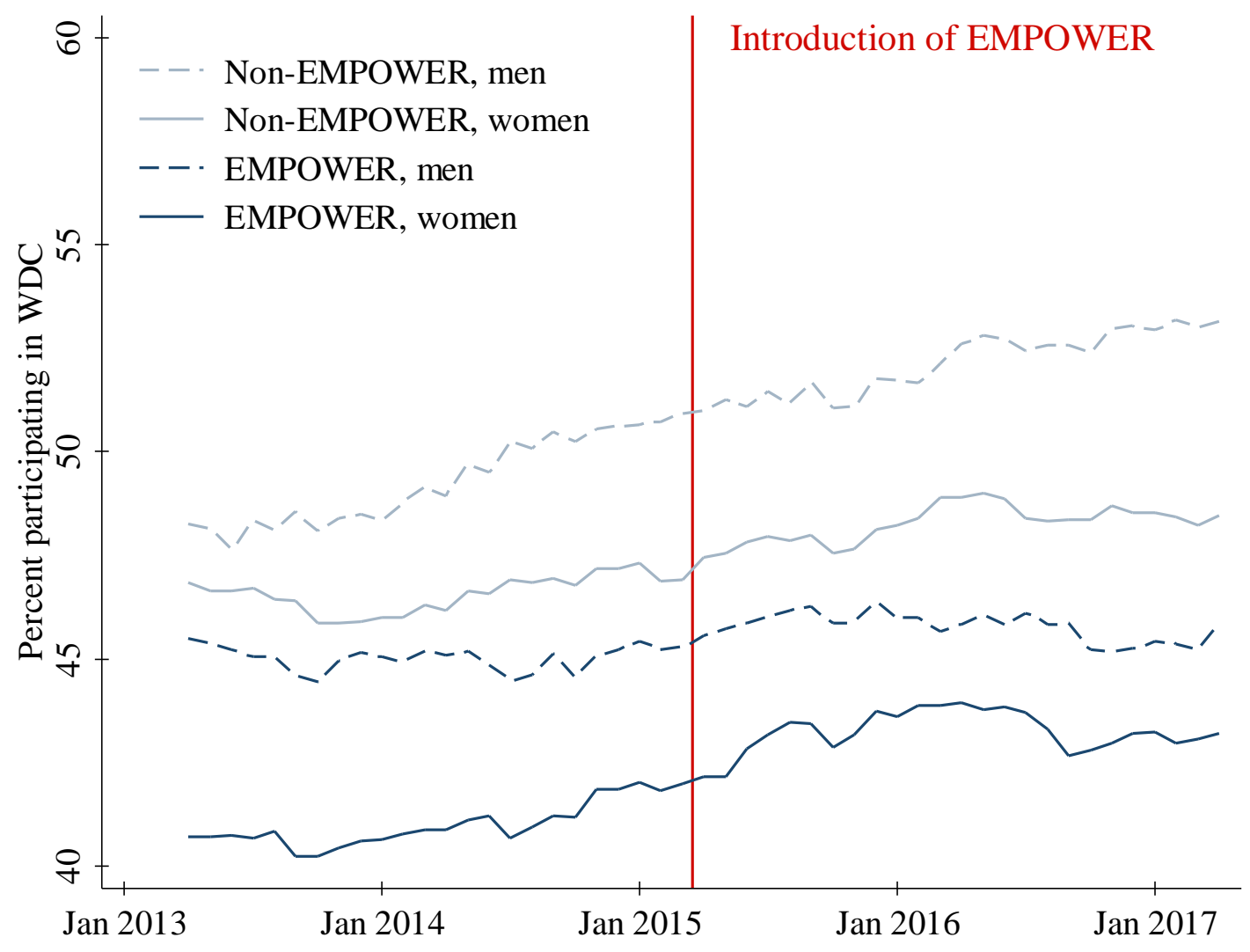

Note: Includes all Wisconsin Retirement System eligible employees at 20 central agencies.

Source: Wisconsin Employee Trust Funds.

There is some suggestion of pre-implementation trends that differ across groups of agencies. Genders at the EMPOWER agencies appear to converge slightly while the opposite happens at non-EMPOWER agencies. Absent any effect of EMPOWER, continuing these trends into the post period could lead to an estimated positive effect. Therefore controlling for trends will be important in the regression analysis.

Figure 6 does not suggest an effect on contributions. For contributions, women lag behind men in both groups of agencies, but the EMPOWER group contributes more on average for both genders. 
Figure 6. Intensive Margin Effects of EMPOWER

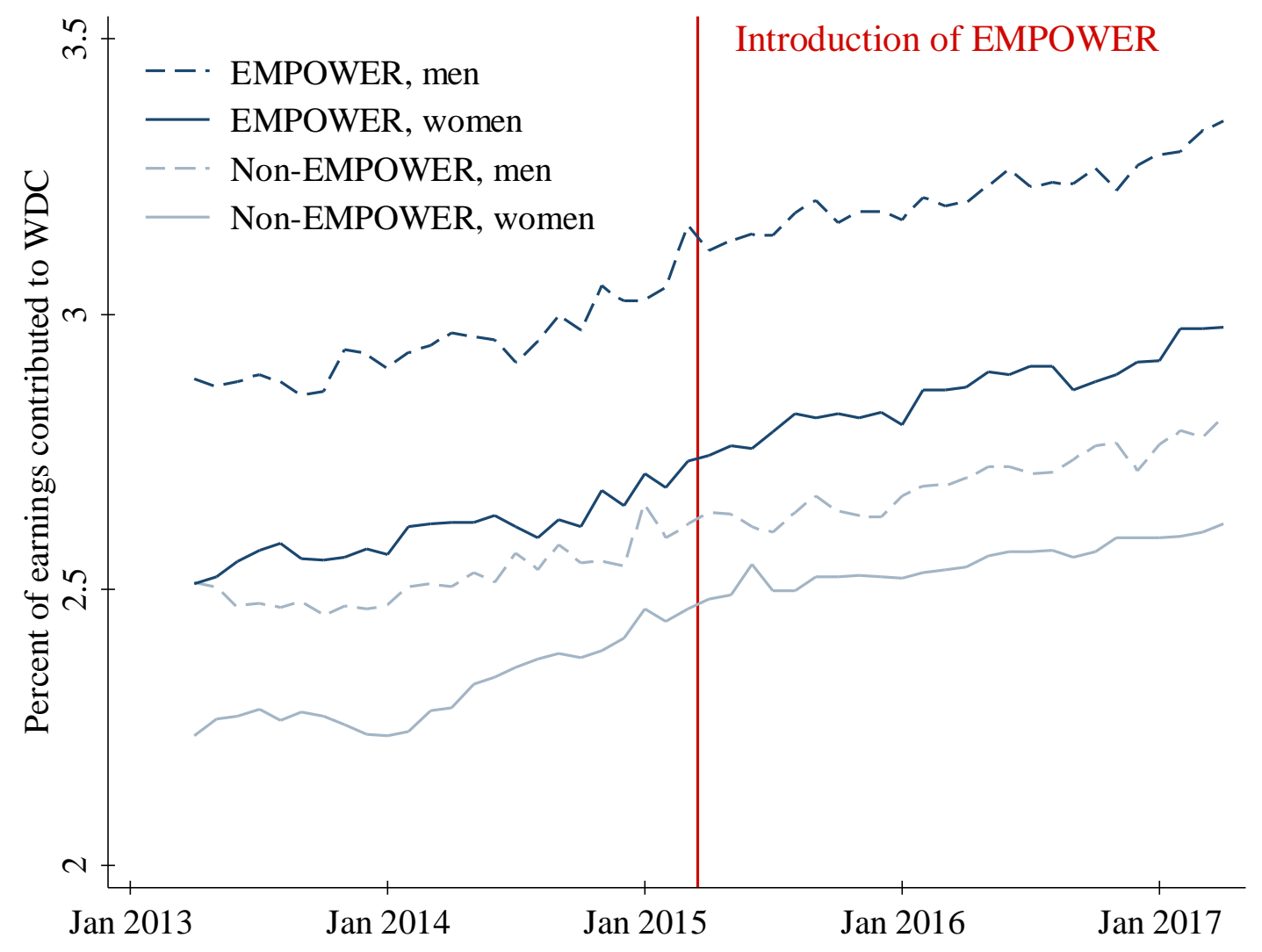

Note: Includes all Wisconsin Retirement System eligible employees at 20 central agencies, who participated in WDC before April 2015.

Source: Wisconsin Employee Trust Funds.

\section{Triple-difference Estimates}

Table 2 averages together all months in the pre-implementation and post-implementation periods for each gender, resulting in eight cell means. Table 2 unpacks the composition of the effect by each difference. Reading the differences, men and women in both groups of agencies increased rates of participation. The differences in differences (DD) by EMPOWER group show that men's participation increased at higher rates at non-EMPOWER agencies, while women's participation increased at higher rates at EMPOWER agencies. The triple-difference uses the non-EMPOWER group as a counterfactual, and thus assumes that women would have lost ground were it not for EMPOWER. The triple-difference effect is therefore larger than the difference-in-difference effect at EMPOWER agencies. 
Table 2. Differences in Differences in the Rate of Participation in WDC

\begin{tabular}{lccccccc}
\hline & \multicolumn{3}{c}{ Non-EMPOWER } & \multicolumn{4}{c}{ EMPOWER } \\
\cline { 2 - 8 } & Pre & Post & Diff. & Pre & Post & Diff. & DD \\
\cline { 2 - 8 } Men & 49.3 & 52.1 & 2.8 & 45.0 & 45.8 & 0.8 & -2.0 \\
Women & 46.6 & 48.3 & 1.7 & 41.0 & 43.2 & 2.2 & 0.5 \\
DD & & & -1.1 & & & 1.4 & \\
DDD & & & & & & & 2.5 \\
\hline
\end{tabular}

Note: Includes all Wisconsin Retirement System eligible employees at 20 central agencies over April 2013 through April 2017. DD: difference in difference. DDD: triple-difference.

Source: Wisconsin Employee Trust Funds.

Table 3 follows the same structure for contributions as a percent of earnings, among workers who participated in the pre-implementation period. All four groups increased contributions on average. However the difference in difference is lower for women than men, leading to a negative triple-difference estimate.

Table 3. Differences in Differences in Contributions to WDC

\begin{tabular}{lccccccc}
\hline & \multicolumn{3}{c}{ Non-EMPOWER } & \multicolumn{4}{c}{ EMPOWER } \\
\cline { 2 - 8 } & Pre & Post & Diff. & Pre & Post & Diff. & DD \\
\cline { 2 - 8 } Men & 2.52 & 2.70 & 0.18 & 2.95 & 3.22 & 0.27 & 0.09 \\
Women & 2.32 & 2.55 & 0.23 & 2.61 & 2.86 & 0.25 & 0.02 \\
DD & & & 0.05 & & & -0.02 & \\
DDD & & & & & & & -0.07 \\
\hline
\end{tabular}

Note: Includes all Wisconsin Retirement System eligible employees at 20 central agencies over April 2013 through April 2017. Restricted to participants in WDC before April 2015. DD: difference in difference. DDD: tripledifference.

Source: Wisconsin Employee Trust Funds.

\section{Regression Adjustments}

The above analysis operates using group means, without accounting for the composition of each group in terms of personal characteristics, and does not report standard errors that account for serial correlation within groups. This subsection presents regression-adjusted results, which support the conclusion of a small positive effect on participation with no apparent effect on contributions among participants. 
Results appear in Table 4. Each line only reports the coefficient (estimate and standard error) of the interaction term representing the effect of EMPOWER from a single regression. Each line successively adds terms to the regression. The first line simply adds standard errors to the estimated triple-differences from the prior tables. The participation result is statistically significant at the 5 percent level. An increase in participation of 2.6 closes the gender gap at EMPOWER agencies by about two thirds.

\section{Table 4. Regression Estimates}

\begin{tabular}{|c|c|c|c|c|}
\hline \multirow[b]{2}{*}{ Specification } & \multicolumn{2}{|c|}{$\begin{array}{c}\text { Participation } \\
(\%)\end{array}$} & \multicolumn{2}{|c|}{$\begin{array}{l}\text { Contributions } \\
\text { (\% of earnings) }\end{array}$} \\
\hline & Coeff. & $(\mathrm{SE})$ & Coeff. & $(\mathrm{SE})$ \\
\hline Equation (1) & 2.64 & $(1.05) * *$ & -0.071 & $(0.081)$ \\
\hline + Person covariates, agency FE, month FE & 2.45 & $(1.01) * *$ & -0.062 & $(0.064)$ \\
\hline + Agency linear time trends & 1.43 & $(1.12)$ & -0.006 & $(0.058)$ \\
\hline + Person FE (excluding agency switchers) & 0.09 & $(0.34)$ & -0.047 & $(0.048)$ \\
\hline All of the above, men only (DD) & 0.67 & $(0.25) * *$ & 0.078 & $(0.044) *$ \\
\hline All of the above, women only (DD) & 1.06 & $(0.31) * * *$ & 0.025 & $(0.013) *$ \\
\hline
\end{tabular}

Note: Contribution outcomes restricted to participants in WDC before April 2015. Rows with person fixed effects exclude 2.2 percent of sample who change employers. Standard errors clustered at agency level. FE: fixed effects. $* p<0.10 * * p<0.05 * * * p<0.01$.

Source: Wisconsin Employee Trust Funds.

Second, we add person covariates and more flexible controls for agency and month. The conclusions are unchanged. Third, we add agency-specific linear time trends. Now the estimated positive effect on participation is smaller and no longer statistically significant. A 1.4 percentage-point increase still closes a large fraction of 4.0 percentage-point the preimplementation gender gap at EMPOWER agencies. However the estimate in this specification is not quite as precise.

The fourth line adds person fixed effects. To focus on the within-person impact of EMPOWER, we leave out the small fraction of workers who change agencies during the panel. This ensures that the most significant temporal change will be exposure to EMPOWER. The within-person estimates show no impact of EMPOWER on participation, and a negative impact on contributions. To unpack this result we separately estimate the regression for men and women. This amounts to a difference-in-difference within each gender. In both cases there are 
positive and statistically significant effects among women. The lack of a triple-difference effect can be explained by an apparent positive effect for men as well. The positive effect among men could indicate they are not a good comparison group, or it could indicate there was some effect of EMPOWER among men as well. Spillovers to men are of course possible with discussions between employees.

The difference-in-difference effects on participation for men somewhat surprisingly have different signs in the raw means versus the trend-adjusted, within-person regression. The raw means suggest that workers at EMPOWER agencies lost ground relative to non-EMPOWER peers. This relationship apparently reverses relative to agency trends. We conclude that controlling for trends is important in this context.

\section{Event Study}

As described above, the data allow for more flexible estimation of effects over time. Here we augment Equation (2) as follows:

$$
Y_{i t}=\sum_{k \neq 0} \rho_{k} T_{E(i t)} F_{i} Q_{k}+\eta_{1} T_{E(i t)} F_{i}+\eta_{2} T_{E(i t)} P_{t}+\eta_{3} F_{i} P_{t}+\gamma T_{E(i t)}+\zeta F_{i}+\delta P_{t}+\varepsilon_{i t}
$$

Here $Q_{k}$ is an indicator for quarter $k$, where $k=0$ represents January through March 2015, the last quarter before EMPOWER was introduced. Because the term for $k=0$ is omitted, the coefficients $\rho_{k}$ represent the triple-difference effects on women's retirement savings of being in quarter $k$ relative to quarter $k=0$. In Equation (1) the analogous comparison is the average of all months April 2015 and later, compared to the average of all months before April 2015. Equation (2) is therefore more flexible.

The assumption that gender gaps move in parallel at EMPOWER agencies and nonEMPOWER agencies can be directly tested by looking at pre-EMPOWER quarters $(k<0)$. Whether the effects of EMPOWER occur immediately, take time to grow, and persist as employees turn over or decide to changes their financial behaviors, can be tested by looking at post-EMPOWER quarters $(k>0)$. Table 5 shows the results. Unlike all other regression reporting, here each line is a coefficient from the same regression. There is one regression estimated for each of the two outcomes. 
Table 5. Event Study Estimates

\begin{tabular}{|c|c|c|c|c|}
\hline \multirow[b]{2}{*}{ Equation (2) } & \multicolumn{2}{|c|}{$\begin{array}{l}\text { Participation } \\
\text { (\%) }\end{array}$} & \multicolumn{2}{|c|}{$\begin{array}{l}\text { Contributions } \\
\text { (\% of earnings) }\end{array}$} \\
\hline & Coeff. & $(\mathrm{SE})$ & Coeff. & (SE) \\
\hline \multicolumn{5}{|c|}{ Pre-EMPOWER } \\
\hline 2013-Q2 & -1.22 & $(0.49)$ & -0.181 & $(0.065) * *$ \\
\hline 2013-Q3 & -1.36 & $(0.25)$ & -0.140 & $(0.072) *$ \\
\hline 2013-Q4 & -1.51 & $(0.20) *$ & -0.147 & $(0.075) *$ \\
\hline 2014-Q1 & -1.18 & $(0.34)$ & -0.111 & $(0.073)$ \\
\hline 2014-Q2 & -0.86 & $(0.25) *$ & -0.084 & $(0.057)$ \\
\hline 2014-Q3 & -1.00 & $(0.31) * * *$ & -0.097 & $(0.044) * *$ \\
\hline 2014-Q4 & -0.30 & $(0.00)$ & -0.061 & $(0.021) * * *$ \\
\hline 2015-Q1 & \multicolumn{4}{|c|}{ (omitted) } \\
\hline \multicolumn{5}{|c|}{ Post-EMPOWER } \\
\hline 2015-Q2 & 0.82 & $(1.05)$ & -0.273 & $(0.106) * *$ \\
\hline 2015-Q3 & 1.81 & $(1.05)$ & -0.221 & $(0.112) *$ \\
\hline 2015-Q4 & 1.70 & $(1.05)$ & -0.209 & $(0.114) *$ \\
\hline 2016-Q1 & 2.23 & $(1.05) *$ & -0.186 & $(0.092) *$ \\
\hline 2016-Q2 & 2.31 & $(1.05) *$ & -0.142 & $(0.109)$ \\
\hline 2016-Q3 & 1.68 & $(1.05)$ & -0.135 & $(0.113)$ \\
\hline 2016-Q4 & 1.44 & $(1.05)$ & -0.133 & $(0.121)$ \\
\hline 2017-Q1 & 1.53 & $(1.05)$ & -0.072 & $(0.121)$ \\
\hline
\end{tabular}

Note: Contribution outcomes restricted to participants in WDC before April 2015. Standard errors clustered at agency level. April 2017 is left out. $* p<0.10 * * p<0.05 * * * p<0.01$.

Source: Wisconsin Employee Trust Funds.

These results confirm again that trends are important in this context. For participation outcomes, the movement from negative coefficients to positive coefficients suggests that gender gaps closed over time at EMPOWER agencies relative to non-EMPOWER agencies, including during the pre-EMPOWER period. However the largest (in magnitude) coefficients appear in the post-EMPOWER period. Not surprisingly, the effects fade over time, as shown in smaller positive coefficients in the last few quarters. The contribution results again do not show clear patterns of effects of EMPOWER. 


\section{Heterogeneous Effects}

The final set of analyses concerns heterogeneous effects by individual characteristics. Financial education has potentially different effects on savings depending on the worker's household finances. Since we cannot directly measure finances, other than observing retirement savings which we use above, we look at household characteristics potentially correlated with financial decisions.

First, we divide the sample by age, into those under 50 years of age (61 percent of the sample) and those 50 years of age or older. Age 50 is the start of catch-up contributions for WDC. Workers in this age group are more likely to be aware of retirement savings, and they do have a higher rate of ever having participated in WDC before EMPOWER (52 percent versus 47 percent). EMPOWER may therefore have more of an impact on younger workers who have a propensity to participate in savings but have not yet done so. Second, we divide the sample by earnings. Above-median earners have much higher rates of participation in WDC before EMPOWER (59 percent versus 38 percent). Like younger workers, lower earners with less exposure to retirement saving may experience larger impacts of financial education.

Finally, we divide workers by whether they are married (63 percent of the sample) or not. Married workers are more likely to have ever participated in WDC before EMPOWER (52 percent versus 42 percent). This difference is an underestimate, as married workers may additionally have access to their spouse's retirement accounts. In addition, according to relative measures of financial literacy in Lusardi and Mitchell (2008), women married to men may have jointly higher financial knowledge in their household than single women. Both trends point to unmarried women seeing larger effects of financial education than married women.

Table 6 displays the results of the simple triple difference specification in Equation (1) for various subgroups. Effects on participation are larger for younger and lower-earning workers, as expected. Effects on participation do not appear to differ strongly based on marital status, but may be slightly greater for married workers. This is surprising given our hypothesis that financial education would have a larger effect on unmarried workers. 
Table 6. Heterogeneous Effects by Age and Marital Status

\begin{tabular}{lcccc}
\hline \multirow{2}{*}{ Subgroup } & \multicolumn{2}{c}{$\begin{array}{c}\text { Participation } \\
\text { (\%) }\end{array}$} & \multicolumn{2}{c}{$\begin{array}{c}\text { Contributions } \\
\text { (\% of earnings) }\end{array}$} \\
\cline { 2 - 6 } Under 50 & Coeff. & (SE) & Coeff. & (SE) \\
\cline { 2 - 6 } 50 or over & 3.64 & $(1.01) * * *$ & -0.224 & $(0.122) *$ \\
Not married & 0.76 & $(0.89)$ & 0.117 & $(0.146)$ \\
Married & 1.34 & $(1.80)$ & -0.156 & $(0.121)$ \\
Below-median earner & 3.42 & $(0.80) * * *$ & -0.036 & $(0.079)$ \\
Above-median earner & 4.06 & $(1.16) * * *$ & -0.046 & $(0.129)$ \\
\hline
\end{tabular}

Note: Contribution outcomes restricted to participants in WDC before April 2015. Standard errors clustered at agency level. FE: fixed effects. $* p<0.10 * * p<0.05 * * * p<0.01$.

Source: Wisconsin Employee Trust Funds.

\section{Discussion and Conclusion}

This study examined a targeted intervention to increase retirement savings among women. Because of the program's implementation, and access to panel data on participants, we are able to investigate the effects of the program, in the context of recent trends among a diverse population of 31,000 workers. EMPOWER appears to increase retirement savings, but results are somewhat dependent on the context and method of estimation. The effect on participation, with no effect on retirement contributions, is consistent with EMPOWER making workers aware of the option to use deferred compensation but not motivating knowledgeable savers to contribute more than they would otherwise.

EMPOWER is implemented at the agency level and is optional to workers. Because the information provided is readily available online, the effects of EMPOWER operate through motivation and empowerment, and making information salient. We do not have individualspecific measures of exposure to the financial education, knowledge gained, or increased motivation. However, the agency-wide estimates of changes in saving behavior are still useful to decision makers considering implementing financial education. Wherever it is costly or infeasible to require education, the "intent to treat" effect of offering education is most relevant.

The benefit of implementing financial education can go beyond simply increasing workers’ well-being. Private-sector retirement plans must meet Actual Deferral Percentage testing, whereby the average salary deferrals of highly compensated employees may not exceed 
that of non-highly compensated employees by too great a margin. Encouraging savings among lower earners, as EMPOWER appears to do, can allow higher earners to reap more tax benefits on retirement savings.

Benefits of financial education following the model of EMPOWER could be quite small and still offset the costs of development and implementation. The main ingredients of EMPOWER were a few days of time from Department of Employee Trust Funds leaders pulling together materials, a few hours of time from lunchtime session leaders, and a few hours of time from agency leaders sending emails.

Our results provide an important contribution to research on financial education for retirement savings. The sample size, frequency, and accuracy of our data are rare in this literature, allowing us to capture with relative precision the effects of EMPOWER on WDC savings. However, we lack the ability to measure expected Social Security benefits of these workers, retirement accounts of spouses, or other household finances that may be affected.

Researchers have come to conflicting conclusions about whether current rates of retirement savings constitute a crisis, and whether information and encouragement should matter (Munnell, Rutledge, and Webb 2014). Our study, showing positive but somewhat fragile effects of financial education, is consistent with households lacking information and encouragement, but it does not settle the debate on the adequacy of savings rates.

EMPOWER is likely to be portable to other contexts at low cost, since it works by making general, publicly available information salient through peer-to-peer engagement. EMPOWER consists of several activities, and because they are delivered together we cannot identify which among them has the greatest impact on financial knowledge, motivation, and saving behavior. Here we focus on gender differences in financial behavior, but prior work in the United Kingdom has shown the importance of personality in this context, and that the effects of personality vary by gender (Kesavayuth, Rosenman, and Zikos 2016). More research is needed to understand all of the causes of gender gaps in saving, and the extent to which financial education can help alleviate them. 


\section{References}

American Association of University Women (AAUW). 2017. "Deeper in Debt: Women and Student Loans.” Washington, DC.

Bajtelsmit, Vickie L., Alexandra Bernasek, and Nancy A. Jianakoplos. 1999. “Gender Differences in Defined Contribution Pension Decisions.” Financial Services Review 8 (1): $1-10$.

Bajtelsmit, Vickie L. and Nancy A. Jianakoplos. 2000. "Women and Pensions: A Decade of Progress?” Issue Brief No. 227. Washington, DC: Employee Benefit Research Institute.

Bernheim, B. Douglas and Daniel M. Garrett. 2003. "The Effects of Financial Education in the Workplace: Evidence from a Survey of Households.” Journal of Public Economics 87: 1487-1519.

Bertrand, Marianne, Esther Duflo, and Sendhil Mullainathan. 2004. "How Much Should We Trust Differences-in-Differences Estimates?” Quarterly Journal of Economics 119(1): 249-275.

Beshears, James, James J. Choi, David Laibson, and Brigitte C. Madrian. 2009. "The Importance of Default Options for Retirement Saving Outcomes: Evidence from the United States.” In Social Security Policy in a Changing Environment, edited by Jeffrey R. Brown, Jeffrey B. Liebman, and David A. Wise, 195-198. Chicago, IL: University of Chicago Press.

Bucher-Koenen, Tabea, Annamaria Lusardi, Rob Alessie, and Marten van Rooij. 2016. "How Financially Literate Are Women? An Overview and New Insights.” Journal of Consumer Affairs 51(2): 255-283.

Collins, J. Michael and Carly Urban. 2016. “The Role of Information on Retirement Planning: Evidence from a Field Study.” Economic Inquiry 54(4): 1860-1872.

Charness, Gary and Uri Gneezy. 2012. "Strong Evidence for Gender Differences in Risk Taking.” Journal of Economic Behavior \& Organization 83(1): 50-58.

Clark, Robert L., Madeleine B. d’Ambrosio, Ann A. McDermed, and Kshama Sawant. 2006. "Retirement Plans and Saving Decisions: The Role of Information and Education." Journal of Pension Economics \& Finance 5(1): 45-67.

Copeland, Craig. 2014. "Employment-Based Retirement Plan Participation: Geographic Differences and Trends, 2013.” Issue Brief No. 405. Washington, DC: Employee Benefit Research Institute.

Dieleman, Joseph L., Ranju Baral, Maxwell Birger, et al. 2016. “U.S. Spending on Personal Health Care and Public Health, 1996-2013.” JAMA 316(24): 2627-2646. 
Duflo, Esther and Emmanuel Saez. 2003. "The Role of Information and Social Interactions in Retirement Plan Decisions: Evidence from a Randomized Experiment.” Quarterly Journal of Economics 118(3): 815-842.

Dwyer, Peggy D., James H. Gilkeson, and John A. List. 2002. “Gender Differences in Revealed Risk Taking: Evidence from Mutual Fund Investors.” Economics Letters 76(2): 151-158.

Fernandes, Daniel, John G. Lynch, Jr., and Richard G; Netemeyer. 2014. "Financial Literacy, Financial Education, and Downstream Financial Behaviors.” Management Science 60(8): 1861-1883.

Fidelity Investments. 2017. “Who’s the Better Investor: Men or Women?” Boston, MA. Available at: https://www.fidelity.com/about-fidelity/individual-investing/better-investor$\underline{\text { men-or-women }}$

Gale, William G., John Karl Scholz, and Ananth Seshadri. 2009. “Are All Americans Saving 'Optimally’ for Retirement?” Working Paper. Madison, WI: University of WisconsinMadison.

Goldin, Claudia. (2014). “A Grand Gender Convergence: its Last Chapter.” American Economic Review 104(4): 1091-1119.

Hastings, Justine S., Brigitte C. Madrian, and William L. Skimmyhorn. 2013. "Financial Literacy, Financial Education, and Economic Outcomes.” Annual Review of Economics 2013(5): 347-373.

Holden, Karen and Sara Kock. 2012. “Understanding Gender Disparities in Tax-Deferred Retirement Account Balances: Saving Through the Wisconsin Deferred Compensation Program.” La Follette School Working Paper No. 2012-011. Madison, WI: University of Wisconsin-Madison.

Lusardi, Annamaria and Olivia S. Mitchell. 2007. "Financial Literacy and Retirement Preparedness: Evidence and Implications for Financial Education.” Business Economics January 2007: 35-44.

Lusardi, Annamaria and Olivia S. Mitchell. 2008. "Planning and Financial Literacy: How Do Women Fare?” American Economic Review 98(2): 413-417.

Lusardi, Annamaria and Olivia S. Mitchell. 2014. “The Economic Importance of Financial Literacy: Theory and Evidence.” Journal of Economic Literature 52(1): 5-44.

Karlsson, Niklas, George Loewenstein, and Duane Seppi. 2009. “The Ostrich Effect: Selective Attention to Information.” Journal of Risk and Uncertainty 38(2): 95-115.

Kesavayuth, Dusanee, Robert E. Rosenman, and Vasileios Zikos. 2016. "Retirement, Personality, and Well-Being.” Economic Inquiry 54: 733-750. 
Moulton, Brent R. 1986. "Random Group Effects and the Precision of Regression Estimates.” Journal of Econometrics 32(3): 385-397.

Munnell, Alicia H. 2004. “Why Are So Many Older Women Poor?” Just the Facts 10. Chestnut Hill, MA: Center for Retirement Research at Boston College.

Munnell, Alicia H., Geoffrey T. Sanzenbacher, and Sara Ellen King. 2017. "Do Women Still Spend Most of Their Lives Married?” Issue in Brief 17-14. Chestnut Hill, MA: Center for Retirement Research at Boston College.

Munnell, Alicia H., Jean-Pierre Aubry, Josh Hurwitz, and Laura Quinby. 2011. "A Role for Defined Contribution Plans in the Public Sector.” State and Local Plans Issue in Brief 16. Chestnut Hill, MA: Center for Retirement Research at Boston College.

Munnell, Alicia H., Matthew S. Rutledge, and Anthony Webb. 2014. “Are Retirees Falling Short? Reconciling the Conflicting Evidence.” Working Paper 2014-16. Chestnut Hill, MA: Center for Retirement Research at Boston College.

Papke, Leslie E. 1998. "How Are Participants Investing Their Accounts in Participant Directed Individual Account Plans?” American Economic Review Papers and Proceedings 88(2): 212-216.

Papke, Leslie E. 2003. "Individual Financial Decisions in Retirement Saving Plans: The Role of Participant-Direction.” Journal of Public Economics 88: 39-61.

Papke, Leslie E., Lina Walker, and Michael Dworsky. 2008. "Retirement Security for Women: Progress to Date and Policies for Tomorrow.” The Retirement Security Project No. 20081. Washington, DC.

Prudential Financial. 2015. “Financial Experience \& Behaviors Among Women.” Prudential Research Study 2014-2015. Newark, NJ.

Scholz, John Karl, Ananth Seshadri, and Surachai Khitatrakun. 2006. “Are Americans Saving 'Optimally' for Retirement?” Journal of Political Economy 114(4): 607-643.

Sundén, Annika E. and Brian J. Surette. 1998. "Gender Differences in the Allocation of Assets in Retirement Savings Plans.” American Economic Review Papers and Proceedings 88(2): 207-211.

United States Government Accountability Office (GAO). 2007. Women Face Challenges in Ensuring Financial Security in Retirement. GAO-08-105, a report to Ranking Member, Special Committee on Aging, U.S. Senate. Washington, DC.

Wettstein, Gal and Alice Zulkarnain. 2017. "How Much Long-Term Care Do Adult Children Provide?” Issue in Brief 17-11. Chestnut Hill, MA: Center for Retirement Research at Boston College. 
Wolfers, Justin. 2006. "Did Unilateral Divorce Laws Raise Divorce Rates? A Reconciliation and New Results.” American Economic Review 96(3): 1802-1820.

Young, Jean A. 2015. “Women versus Men in DC Plans.” Valley Forge, PA: Vanguard Research. 


\section{RECENT WORKING PAPERS FROM THE CENTER FOR RETIREMENT RESEARCH AT BOSTON COLLEGE}

Dementia, Help with Financial Management, and Well-Being Anek Belbase and Geoffrey T. Sanzenbacher, September 2017

The Behavioral and Consumption Effects of Social Security Changes Wenliang Hou and Geoffrey T. Sanzenbacher, September 2017

Family Transfers With Retirement-Aged Adults in the United States: Kin Availability, Wealth Differentials, Geographic Proximity, Gender, and Racial Disparities Ashton M. Verdery, Jonathan Daw, Colin Campbell, and Rachel Margolis, August 2017

Guardianship and the Representative Payee Program

Anek Belbase and Geoffrey T. Sanzenbacher, August 2017

The Relative Effects of Economic and Non-Economic Factors on Taxpayers' Preferences Between Front-Loaded and Back-Loaded Retirement Savings Plans Andrew D. Cuccia, Marcus M. Doxey, and Shane R. Stinson, July 2017

Social Security and Total Replacement Rates in Disability and Retirement Mashfiqur R. Khan, Matthew S. Rutledge, and Geoffrey T. Sanzenbacher, May 2017

An Experimental Analysis of Modifications to the Survivor Benefit Information within the Social Security Statement Jeffrey Diebold and Susan Camilleri, May 2017

Actuarial Inputs and the Valuation of Public Pension Liabilities and Contribution Requirements: A Simulation Approach

Gang Chen and David S. T. Matkin, May 2017

Why Are U.S. Households Claiming Social Security Later?

Wenliang Hou, Alicia H. Munnell, Geoffrey T. Sanzenbacher, and Yinji Li, April 2017

Rising Inequality in Life Expectancy by Socioeconomic Status Geoffrey T. Sanzenbacher, Anthony Webb, Candace M. Cosgrove, and Natalia S. Orlova, April 2017

The Effect of Job Mobility on Retirement Timing by Education Geoffrey T. Sanzenbacher, Steven A. Sass, and Christopher M. Gillis, February 2017

All working papers are available on the Center for Retirement Research website (http://crr.bc.edu) and can be requested by e-mail (crr@bc.edu) or phone (617-552-1762). 